\section{Canopy Light Effects in Multiple Training Systems on Yield, Soluble Solids, Acidity, Phenol and Flavonoid Concentration of 'Frontenac' Grapes}

\author{
Christina M. Bavougian ${ }^{1,4}$, Paul E. Read ${ }^{1}$, Vicki L. Schlegel ${ }^{2}$, and \\ Kathryn J. Hanford ${ }^{3}$
}

ADDITIONAL INDEX wORDs. trellis, $P A R$, transmittance, canopy microclimate, fruit composition

Summary. Phenolic compounds contribute greatly to the sensory attributes of wine and have a wide range of human health benefits as well. In this study, four trellis / training systems were evaluated for effects on fruit-zone light environment, fruit chemical composition (including phenol and flavonoid concentrations), and yield of 'Frontenac' grapes ( Vitis sp. MN 1047) grown in southeastern Nebraska over two growing seasons. Photosynthetically active radiation $(P A R)$ was measured above the canopy and within the fruiting zone at berry set, veraison, and harvest. Point quadrat canopy analysis was performed at veraison. Both bound and free (unbound) flavonoid and total phenolic contents were determined for the skins and seeds of fruit samples in 2008. At all sampling dates in 2008, vines grown on Geneva double curtain (GDC) and high cordon (HC) had higher midday percentage $P A R$ transmittances than vines grown on Smart-Dyson (SD) and vertical shoot positioned (VSP) training systems. In 2009, transmittance relationships between trellises were not consistent throughout the season. In both years, leaf layer number (LLN) was lower for GDC and HC than for SD and VSP. Flavonoid and total phenol concentrations of the bound seed and bound skin extracts did not differ among trellises. Within the free extracts, VSP had higher total phenol concentration than SD (GDC and HC were intermediate) and there were no differences in flavonoid concentration. In 2008, GDC had higher $\mathrm{pH}$ than other trellises and higher soluble solids than SD and VSP; titratable acidity (TA) was lower in GDC and HC than in SD and VSP. In 2009, SD and VSP had the highest soluble solids concentrations; $\mathrm{HC}$ had lower $\mathrm{pH}$ than SD and VSP and there were no differences in TA. Results were inconclusive regarding light environment effects on fruit chemical composition.

$\mathrm{P}$ henolic compounds include a diverse group of substances that perform a variety of functions in vascular plants. Phenolics are commonly divided into flavonoid (tannins, anthocyanins, flavan-3-ols, and

This paper was prepared in partial fulfillment of a degree requirement (M.S. thesis)

This research was jointly funded by the University of Nebraska Agricultural Research Division and the Nebraska Grape and Wine Board.

We thank Stephen Gamet and Issam Qrunfleh for their assistance with the field portion of this research and Elizabeth Walter-Shea for advice and equipment. We also acknowledge the guidance of Charles Francis.

${ }^{1}$ Department of Agronomy and Horticulture, University of Nebraska-Lincoln, 377 Plant Science Hall, Lincoln, NE 68583-0724

${ }^{2}$ Department of Food Science and Technology, University of Nebraska-Lincoln, 326 Food Industry Complex, Lincoln, NE 68583-0919

${ }^{3}$ Department of Statistics, University of NebraskaLincoln, 343A Hardin Hall North, Lincoln, NE 68583-0963

${ }^{4}$ Corresponding author. E-mail: christina.huck@huskers. unl.edu. flavonols) and nonflavonoid (hydroxycinnamates and stilbenes) compounds (Cheynier et al., 1999). Flavonoids are differentiated from nonflavonoid phenolics by their carbon skeleton (Kennedy et al., 2006). Most phenolics are purported to protect plants from ultraviolet radiation damage; some help defend against bacterial and fungal infection (Downey et al., 2006). Anthocyanins and other pigments attract animals that perform such services as pollination and seed dispersal (Downey et al., 2006). Tannins and flavan-3-ols discourage herbivory because of their astringent and/or bitter flavors (Santos-Buelga and Scalbert, 2000).

In addition to their many functions within plants, polyphenols contribute greatly to the sensory attributes of wine; increased concentration has generally been associated with high quality (Cheynier et al., 2006; Reynolds et al., 1995; Ristic et al., 2007). According to Downey et al. (2006), wine flavonoid content is mostly determined by grape composition and only partly by winemaking procedures; however, Holt et al. (2008a, 2008b) demonstrated that increased total phenol, tannin, and anthocyanin concentrations in must did not have an effect on wine quality scores.

A majority of the research on phenolic compounds has focused on their positive effects on human health. The capacity to neutralize free radicals (reactive molecules that cause mutations, heart disease, skin problems, and aging), also called antioxidant activity (AOA), is common to phenolics as a group (Iacopini et al., 2008). The AOA of many polyphenols is much greater than that of the essential dietary vitamins, and grapes and wine contain some of the highest phenol concentrations in the human diet (Iacopini et al., 2008). In addition to their antioxidant properties, phenolics act as anti-inflammatory agents to improve human health. Polyphenols in wine reduce the risk of cardiovascular disease (Fang et al., 2008) in two ways: by inhibiting the aggregation of

\begin{tabular}{llll}
\hline $\begin{array}{l}\text { Units } \\
\text { To convert U.S. to SI, } \\
\text { multiply by }\end{array}$ & U.S. unit & SI unit & $\begin{array}{l}\text { To convert SI to U.S., } \\
\text { multiply by }\end{array}$ \\
\hline 10 & $\%$ & $\mathrm{~g} \cdot \mathrm{L}^{-1}$ & 0.1 \\
0.4047 & $\mathrm{acre}(\mathrm{s})$ & $\mathrm{ha}$ & 2.4711 \\
29,574 & $\mathrm{fl} \mathrm{oz}$ & $\mu \mathrm{L}$ & $3.3814 \times 10^{-5}$ \\
29.5735 & $\mathrm{fl} \mathrm{oz}$ & $\mathrm{mL}$ & 0.0338 \\
0.3048 & $\mathrm{ft}$ & $\mathrm{m}$ & 3.2808 \\
2.54 & inch(es) & $\mathrm{cm}$ & 0.3937 \\
25.4 & inch(es) & $\mathrm{mm}$ & 0.0394 \\
0.4536 & $\mathrm{lb}$ & $\mathrm{kg}$ & 2.2046 \\
1.6093 & $\mathrm{mile}(\mathrm{s})$ & $\mathrm{km}$ & 0.6214 \\
28.3495 & $\mathrm{oz}$ & $\mathrm{g}$ & 0.0353 \\
0.001 & $\mathrm{ppm}$ & $\mathrm{mg} \cdot \mathrm{g}^{-1}$ & 1000 \\
0.9072 & $\mathrm{t}(\mathrm{s})$ & $\mathrm{Mg}$ & 1.1023 \\
$\left({ }^{\circ} \mathrm{F}-32\right) \div 1.8$ & ${ }^{\circ} \mathrm{F}$ & ${ }^{\circ} \mathrm{C}$ & $\left({ }^{\circ} \mathrm{C} \times 1.8\right)+32$
\end{tabular}


platelets and by protecting low-density lipoprotein (LDL) cholesterol against oxidation (Santos-Buelga and Scalbert, 2000). Phenolics also protect against lung cancer, act as general antitumoral and anticarcinogenic agents, reduce systolic blood pressure, and lower plasma cholesterol levels (Fang et al., 2008; Santos-Buelga and Scalbert, 2000).

The light environment within the canopy is the most important factor influencing grapevine yield and quality (Dokoozlian and Kliewer, 1995; Smart and Robinson, 1991). Trellises or training systems determine the spacing and orientation of shoots, thereby controlling light interception in the canopy (Dokoozlian and Kliewer, 1995; Howell et al., 1991). It is generally agreed that shading of berries reduces total phenol concentrations (Cortell and Kennedy, 2006; Morrison and Noble, 1990; Wolf et al., 2003), and that fruit shading reduces wine phenolic content (Joscelyne et al., 2007; Macaulay and Morris, 1993; Ristic et al., 2007), but results have not always been consistent.

As well as affecting the total phenol concentration in grapes, shading also changes the relative abundance of various phenolic components. Shade treatments increased seed tannins (low molecular weight) relative to skin tannins (high molecular weight) (Ristic et al., 2007). When Downey et al. (2004) applied artificial shading to 'Shiraz' clusters, flavonol synthesis was decreased although there was no significant effect on anthocyanin or tannin concentrations. In another study, sunlight-exposed clusters contained nearly 10 times the amount of flavonol of fruit grown in the shade (Spayd et al., 2002). Some authors observed that fruit shading decreased total anthocyanin concentration and altered its composition (Koyama and GotoYamamoto, 2008; Price et al., 1995; Smart et al., 1988). Artificial shading did not change the amount of anthocyanins in fruit although it did change the composition; however, wines made from the shaded grapes had lower anthocyanin concentration than wines made from sunlit grapes (Ristic et al., 2007). In a study of the effects of artificial shade and increased sun exposure on wine quality, wines made from shaded fruit contained lower concentrations of anthocyanins and were less astringent than control wines.
Yet anthocyanin concentration and astringency of wines made from experimentally exposed fruit did not differ significantly from control wines (Joscelyne et al., 2007). Morrison and Noble (1990) compared wines made from differently shaded 'Cabernet Sauvignon' fruit. Cluster shading decreased the anthocyanin content of wines, but sensory analysis yielded no corresponding differences in flavor or perceived aromas (Morrison and Noble, 1990). Total phenolic content of 'Shiraz' fruit was correlated with the percentage of ambient $P A R$ (wavelength $400-700 \mathrm{~nm}$ ) available in the fruit zone, but anthocyanin concentration was not related to $P A R$ (Wolf et al., 2003).

The influence of fruit-zone light environment on phenolic compounds in classical red wine grapes has been extensively studied, but similar research has not been performed on cold climate hybrid grapes in general and on 'Frontenac' in particular. This is particularly significant because the genetic background of 'Frontenac' consists largely of Vitis riparia, whereas cited studies involve Vitis vinifera cultivars (Minnesota Agricultural Experiment Station, 2008).

Because previous investigations have yielded such varied and complex results, it is problematic to draw conclusions, especially for a relatively new cultivar. Therefore, this study was designed to determine if chemical composition of 'Frontenac' fruit is influenced by light intensity within the canopy. In addition to soluble solids, $\mathrm{pH}$, and titratable acidity, we measured total phenolic and flavonoid concentrations of the fruit to provide a broader perspective.

\section{Materials and methods}

RESEARCH SITE AND EXPERIMENTAL DESIGN. Research for this study was conducted at a commercial vineyard 4 miles north of Wilber, NE (lat. $40^{\circ} 32^{\prime \prime} \mathrm{N}$, long. $97^{\circ} \mathrm{W}$ ) during 2008 and 2009. The soil is a Crete series (very deep, moderately well-drained, fine Pachic Argiustoll) silty clay loam with $1 \%$ to $3 \%$ slope. The vineyard was not irrigated during the study. 'Frontenac' vines (Vitissp. MN 1047) planted in 2004-05 were trained to four different trellis styles GDC (horizontally divided bilateral HC system with downward shoot positioning), $\mathrm{HC}$ (single bilateral HC system with downward shoot positioning), SD (vertically divided canopy arising from a single midcordon with upward and downward shoot positioning), and VSP (single bilateral low- or midcordon system with upward shoot positioning)]. The training systems used in this study are described and illustrated in detail by Smart and Robinson (1991) and by Dami et al. (2005). Rows were oriented north-south with vines $2.4 \mathrm{~m}$ apart and rows $3 \mathrm{~m}$ apart. The training systems were each applied to an entire 120-m row except for VSP ( 1.5 rows). The vineyard was subject to standard cultural practices for the area (permanent sod alleyways and bare under-row strips maintained with herbicide) and all vines were spur pruned. Each vine was assigned a number; sample plants from each treatment were selected using a random number generator $(n=20$ for GDC, HC, and SD; $n=30$ for VSP). The number of sample plants was constrained by the time it took to record light measurements.

Light measurements. Photosynthetically active radiation was measured with a line quantum sensor (LI-191; LI-COR Biosciences, Lincoln, NE) and recorded by a data logger (Polycorder 720 series; Wescor Environmental Products, Logan, UT) both above the canopy and within the fruit zones $(8$ inches above the cordon for SD and VSP, 8 inches below the cordon for GDC and HC) of sample plants. For the GDC vines we took fruit-zone $P A R$ measurements in the west canopy, and for $\mathrm{SD}$ we used the upper canopy. PAR measurements were performed on three dates during each growing season $\{25$ June, 31 July, 29 Aug. 2008 [day of the year (DOY) 177, 213, 242]; 29 June, 8 Aug., 18 Sept. 2009 (DOY 180, 220, 261)\}. Sampling dates were chosen to correspond to key phenological stages: berry set, veraison, and harvest. The dates we chose for sampling were near typical harvest dates for 'Frontenac' in this area, although fruit was harvested before the corresponding PAR measurements in both years of study. On each sampling date, $P A R$ measurements were obtained for each plant between 1200 and $1400 \mathrm{HR}$, within $1 \mathrm{~h}$ of solar noon. Sample plants were marked so that the instrument could be inserted into the canopy in the same place each time. Percentage PAR transmittances 
Table 1. Mean midday fruit-zone percentage photosynthetically active radiation ( $P A R)$ transmittances of 'Frontenac' grapes grown on four training systems in southeastern Nebraska in 2008 and $2009 .^{2}$

\begin{tabular}{|c|c|c|c|c|c|c|}
\hline \multirow[b]{2}{*}{ Trellis $^{\mathrm{y}}$} & $\begin{array}{l}2008 \text { Bloom } \\
(\text { DOY 177) } \\
\end{array}$ & $\begin{array}{c}2008 \text { Veraison } \\
\text { (DOY 213) }\end{array}$ & $\begin{array}{l}2008 \text { Harvest } \\
\text { (DOY 242) }\end{array}$ & $\begin{array}{l}2009 \text { Bloom } \\
\text { (DOY 180) }\end{array}$ & $\begin{array}{l}2009 \text { Veraison } \\
\text { (DOY 220) }\end{array}$ & $\begin{array}{l}2009 \text { Harvest } \\
\text { (DOY 261) }\end{array}$ \\
\hline & \multicolumn{6}{|c|}{$P A R$ transmittance $(\%)$} \\
\hline GDC & $0.50 \mathrm{a}^{\mathrm{w}}$ & $0.19 \mathrm{a}$ & $0.43 \mathrm{a}$ & $0.27 \mathrm{a}$ & $0.24 \mathrm{a}$ & $0.63 \mathrm{a}$ \\
\hline $\mathrm{HC}$ & $0.48 \mathrm{a}$ & $0.23 \mathrm{a}$ & $0.36 \mathrm{a}$ & $0.25 \mathrm{a}$ & $0.22 \mathrm{a}$ & $0.52 \mathrm{~b}$ \\
\hline SD & $0.16 \mathrm{~b}$ & $0.08 \mathrm{~b}$ & $0.16 \mathrm{~b}$ & $0.08 \mathrm{~b}$ & $0.11 \mathrm{~b}$ & $0.30 \mathrm{c}$ \\
\hline VSP & $0.21 \mathrm{~b}$ & $0.06 \mathrm{~b}$ & $0.21 \mathrm{~b}$ & $0.11 \mathrm{~b}$ & $0.20 \mathrm{a}$ & $0.33 \mathrm{c}$ \\
\hline
\end{tabular}

${ }^{2}$ The statistical models included the fixed effects of year $(P=0.1452)$, trellis $(P<0.0001)$, date $(P<0.0001)$, year by date $(P<0.0001)$, year by trellis $(P=0.0276)$, trellis by date by year $(P<0.0001)$, and a random plant effect. Because there was a significant trellis by date by year interaction, the trellis by date interaction was investigated by year. ${ }^{\mathrm{V}} \mathrm{GDC}=$ Geneva double curtain, $\mathrm{HC}=$ high cordon, $\mathrm{SD}=$ Smart-Dyson, VSP $=$ vertical shoot positioning.

${ }^{x} \mathrm{DOY}=$ Day of the year.

wLeast square means followed by the same letter within a column do not differ at $P \leq 0.05$ using Tukey's adjustment.

Table 2. Mean yield and leaf layer number (LLN) of 'Frontenac' grapes grown on four training systems in southeastern Nebraska in 2008 and 2009. ${ }^{\mathrm{z}}$

\begin{tabular}{lccc}
\hline Trellis $^{\mathrm{y}}$ & $\begin{array}{c}\text { 2008 Yield } \\
(\mathbf{k g} / \text { plant })^{\mathrm{x}}\end{array}$ & $\begin{array}{c}\text { 2009 Yield } \\
(\mathbf{k g} / \text { plant })\end{array}$ & $\begin{array}{c}\text { 2008-09 } \\
\text { LLN (no.) }\end{array}$ \\
\hline GDC & 2.36 & $4.21 \mathrm{a}^{\mathrm{v}}$ & $1.29 \mathrm{~b}$ \\
HC & 1.10 & $2.52 \mathrm{c}$ & $1.45 \mathrm{~b}$ \\
SD & 1.34 & $3.73 \mathrm{ab}$ & $2.27 \mathrm{a}$ \\
VSP & 1.34 & $3.01 \mathrm{bc}$ & $2.19 \mathrm{a}$ \\
\hline
\end{tabular}

${ }^{2}$ For 2009 yield analysis, the statistical models included the fixed effect of trellis $(P=0.0006)$. For LLN analysis, the models included fixed effects of trellis $(P<0.0001)$, year $(P=0.004)$, year by trellis $(P=0.7533)$, and a random plant effect. Because there was not a significant year by trellis interaction, the data are averaged over both years. ${ }^{\mathrm{V}} \mathrm{GDC}=$ Geneva double curtain, $\mathrm{HC}=$ high cordon, $\mathrm{SD}=$ Smart-Dyson, VSP $=$ vertical shoot positioning. ×2008 yield means not statistically compared because harvest weights for individual vines were not measured that year. Yields per plant are calculated from whole-plot crop weights in 2008. In 2009, each vine was harvested separately and yields per plant recorded; $1 \mathrm{~kg}=2.2046 \mathrm{lb}$

wLLN calculated from point quadrat data.

${ }^{\vee}$ Means followed by the same letter within a column do not differ at $P \leq 0.05$ using Tukey's adjustment.

were calculated by dividing the fruitzone $P A R$ value by the ambient $P A R$ (measured above the canopy).

POINT QUADRAT CANOPY ANALYSIS. On 8 Aug. of both years [DOY 221 (2008), DOY 220 (2009)], point quadrat analysis was performed as described by Smart and Robinson (1991). Three insertions were made for each sample plant. Point quadrat data were used to compute LLN.

YIELD AND BERRY COMPOSITION. Bird-proof netting was used to protect the crop in both years of study. Netting was in place from veraison through harvest. Fruit was harvested on 15 Aug. 2008 (DOY 228) and 19 Aug. 2009 (DOY 231). In 2008, fruit was collected from each treatment and weighed. Average yield per plant was then calculated from those sums (2008 yield data not subject to statistical analysis). In 2009, fruit from each sample plant was harvested separately and weighed. At both years' harvests, randomly selected 30 berry samples were collected from each sample plant, placed in resealable plastic bags and frozen until laboratory analysis. Berry samples were weighed, thawed, wrapped in cheese cloth and then crushed with a mortar and pestle. Juice was reserved for analysis (both years) and fruit solids were returned to their bags and refrozen (2008). Juice $\mathrm{pH}$ was measured with a digital $\mathrm{pH}$-meter (Orion model 611; Thermo Fisher Scientific, Waltham, MA). Soluble solids were measured using a digital refractometer (model PR-101; Atago, Bellevue, WA). Titratable acidity (TA) was determined by titration with sodium hydroxide $(\mathrm{NaOH})$, using an automatic TA test (model 620F-1; Kimax, Vineland, NJ). Phenolic analysis was carried out in 2008, but not in 2009 because of personnel limitations.

Total PHENOL EXTRACTION. Total phenol extraction was performed using the method described by Gorinstein et al. (2010). Berry samples were thawed; skins and seeds were separated from pulp and dried to constant weight in an Isotemp vacuum oven (model 280A, Thermo Fisher Scientific) at $60{ }^{\circ} \mathrm{C}$ for $\approx 24 \mathrm{~h}$. After crushing seeds with a mortar and pestle and skins with a metal spatula, small portions of the samples were placed in $15-\mathrm{mL}$ plastic tubes for extraction $(\approx 0.19 \mathrm{~g}$ for seeds and $0.21 \mathrm{~g}$ for skins). Free, or unbound, phenols were extracted with 50\% methanol: $50 \%$ water. Two milliliters of solvent was added to each seed sample; skin samples received $3 \mathrm{~mL}$. After shaking for $\mathrm{l} \mathrm{h}$ on a shaker (Labquake; Barnstead Thermolyne, Dubuque, IA), the samples were centrifuged for $15 \mathrm{~min}$ at $8000 g_{\mathrm{n}}$ and supernatants reserved. The process was repeated once for seeds and twice for skins, for a total of 4 and $9 \mathrm{~mL}$ of solvent, respectively. Bound phenols (those glycosylated to larger molecules or ligans) were extracted from the same pellets, using the procedure previously described, with a solution of $50 \%$ methanol: $50 \%$ water and $1.2 \mathrm{~N}$ hydrochloric acid. The bound extraction was performed twice for both seeds and skins, yielding 4 and $6 \mathrm{~mL}$ of supernatant, respectively.

Phenol content assay. Phenolic content was determined using the method described in Singleton and Rossi (1965). To perform the assay, $100 \mu \mathrm{L}$ of $2 \mathrm{~N}$ Folin-Ciocalteu reagent (Sigma-Aldrich, St. Louis, MO), $4.5 \mathrm{~mL}$ nanopure water, and $0.3 \mathrm{~mL}$ $2 \%(\mathrm{w} / \mathrm{v})$ sodium carbonate $\left(\mathrm{Na}_{2} \mathrm{CO}_{3}\right)$ were added to the sample extracts, which were diluted as follows: $5 \mu \mathrm{L}$ of free seed extract, $10 \mu \mathrm{L}$ of free skin extract, and $20 \mu \mathrm{L}$ of bound seed extract were combined with nanopure water to a final volume of $100 \mu \mathrm{L}$. The bound skin extract was not diluted. The mixture was shaken intermittently for $2 \mathrm{~h}$. The absorbance was measured at $760 \mathrm{~nm}$ with a spectrophotometer (model DU800; Beckman Coulter, Brea, CA), and compared with a trans-cinnamic acid standard curve. Results were calculated as concentrations (milligrams per gram dry sample). 
Flavonoid content assay. Flavonoid concentration was determined using the methods described in Adom and Liu (2002) and Jia et al. (1999). To perform the assay, $0.625 \mathrm{~mL}$ nanopure water, $37.5 \mu \mathrm{L} 5 \%(\mathrm{w} / \mathrm{v})$ sodium nitrite $\left(\mathrm{NaNO}_{2}\right), 74 \mu \mathrm{L} 10 \%$ $(\mathrm{w} / \mathrm{v})$ aluminum chloride $\left(\mathrm{AlCl}_{3}\right)$, $0.25 \mathrm{~mL} 4.0 \mathrm{M} \mathrm{NaOH}$, and additional $0.4 \mathrm{~mL}$ nanopure water was added to $125 \mu \mathrm{L}$ of sample extract. Seed extracts were diluted at ratios of 1 part extract in 9 parts nanopure water (free) and 1 part extract in 4 parts water (bound); skin extracts were not diluted. The mixture was vortexed to distribute any precipitate that formed. The absorbance was measured at $510 \mathrm{~nm}$ and compared with a $(+)$-catechin standard curve. Results were calculated as concentrations (milligrams per gram dry sample).

Statistical analysis. Statistical analyses were performed using the GLIMMIX procedure of SAS ${ }^{\circledR}$ (version 9.3; SAS Institute, Cary, NC). For those variables measured on the same plants once each year (harvest variables and point quadrat data) an initial mixed linear repeated measures model with fixed effects of trellis and year and a trellis by year interaction was used. The residual matrix was tested with both the unstructured and independent covariance structures and the one with the smallest Aikake's information criteria was used. The PAR measurements were analyzed using an initial mixed linear repeated measures model with the fixed effects of trellis, year, and month, as well as their interactions and a random plant effect. The residual matrix was tested the same as for the other repeated measures models. Total phenol and flavonoid results were examined using a linear model with fixed

Table 3. Mean fruit characteristics of 'Frontenac' grown on four training systems in southeastern Nebraska in 2008 and 2009. ${ }^{\mathrm{z}}$

\begin{tabular}{|c|c|c|c|c|c|c|c|c|}
\hline Trellis $^{\mathrm{y}}$ & $\begin{array}{c}2008 \text { Berry } \\
\text { wt }(g)^{x}\end{array}$ & $\begin{array}{l}2008 \text { Soluble } \\
\text { solids (\%) }\end{array}$ & $2008 \mathrm{pH}$ & $\begin{array}{c}2008 \\
\mathrm{TA}\left(\mathrm{g} \cdot \mathrm{L}^{-1}\right)^{\mathrm{w}} \\
\end{array}$ & $\begin{array}{c}2009 \text { Berry } \\
\text { wt }(\mathrm{g})\end{array}$ & $\begin{array}{c}2009 \text { Soluble } \\
\text { solids (\%) }\end{array}$ & $2009 \mathrm{pH}$ & $\begin{array}{c}2009 \text { TA } \\
\left(\mathrm{g} \cdot \mathrm{L}^{-1}\right) \\
\end{array}$ \\
\hline GDC & $1.08 \mathrm{a}^{\mathrm{v}}$ & $22.45 \mathrm{a}$ & $3.06 \mathrm{a}$ & $17.9 \mathrm{~b}$ & $0.85 \mathrm{ab}$ & $20.35 \mathrm{~b}$ & $3.10 \mathrm{ab}$ & $15.7 \mathrm{a}$ \\
\hline $\mathrm{HC}$ & $1.10 \mathrm{a}$ & $21.50 \mathrm{ab}$ & $2.95 \mathrm{~b}$ & $18.6 \mathrm{~b}$ & $0.82 \mathrm{~b}$ & $19.74 \mathrm{~b}$ & $3.05 \mathrm{~b}$ & $14.6 \mathrm{a}$ \\
\hline SD & $1.12 \mathrm{a}$ & $20.81 \mathrm{bc}$ & $2.93 \mathrm{~b}$ & $20.9 \mathrm{a}$ & $0.88 \mathrm{a}$ & $21.58 \mathrm{a}$ & $3.12 \mathrm{a}$ & $15.2 \mathrm{a}$ \\
\hline VSP & $1.09 \mathrm{a}$ & $20.35 \mathrm{c}$ & $2.92 \mathrm{~b}$ & $20.4 \mathrm{a}$ & $0.88 \mathrm{a}$ & $21.42 \mathrm{a}$ & $3.12 \mathrm{a}$ & $15.0 \mathrm{a}$ \\
\hline
\end{tabular}

${ }^{z}$ The statistical models included the fixed effects of year, trellis, their interactions, and a random plant effect. Statistical probability values for year, trellis, and their interaction for berry weight were $<0.0001,0.1642$, and $<0.0001$; for soluble solids were $0.0539,0.1755$, and $<0.0001$; for $\mathrm{pH}$ were $<0.0001,0.0003$, and $<0.0001$; and for TA were $<0.0001,0.0130$, and 0.0033 , respectively.

${ }^{y} \mathrm{GDC}=$ Geneva double curtain, $\mathrm{HC}=$ high cordon, $\mathrm{SD}=$ Smart-Dyson, VSP = vertical shoot positioning.

${ }^{\mathrm{x}} \mathrm{lg}=0.0353 \mathrm{oz}$.

wA = titratable acidity, $1 \mathrm{~g} \cdot \mathrm{L}^{-1}=0.1 \%$.

"Means followed by the same letter within a column do not differ at $P \leq 0.05$ using Tukey's adjustment.

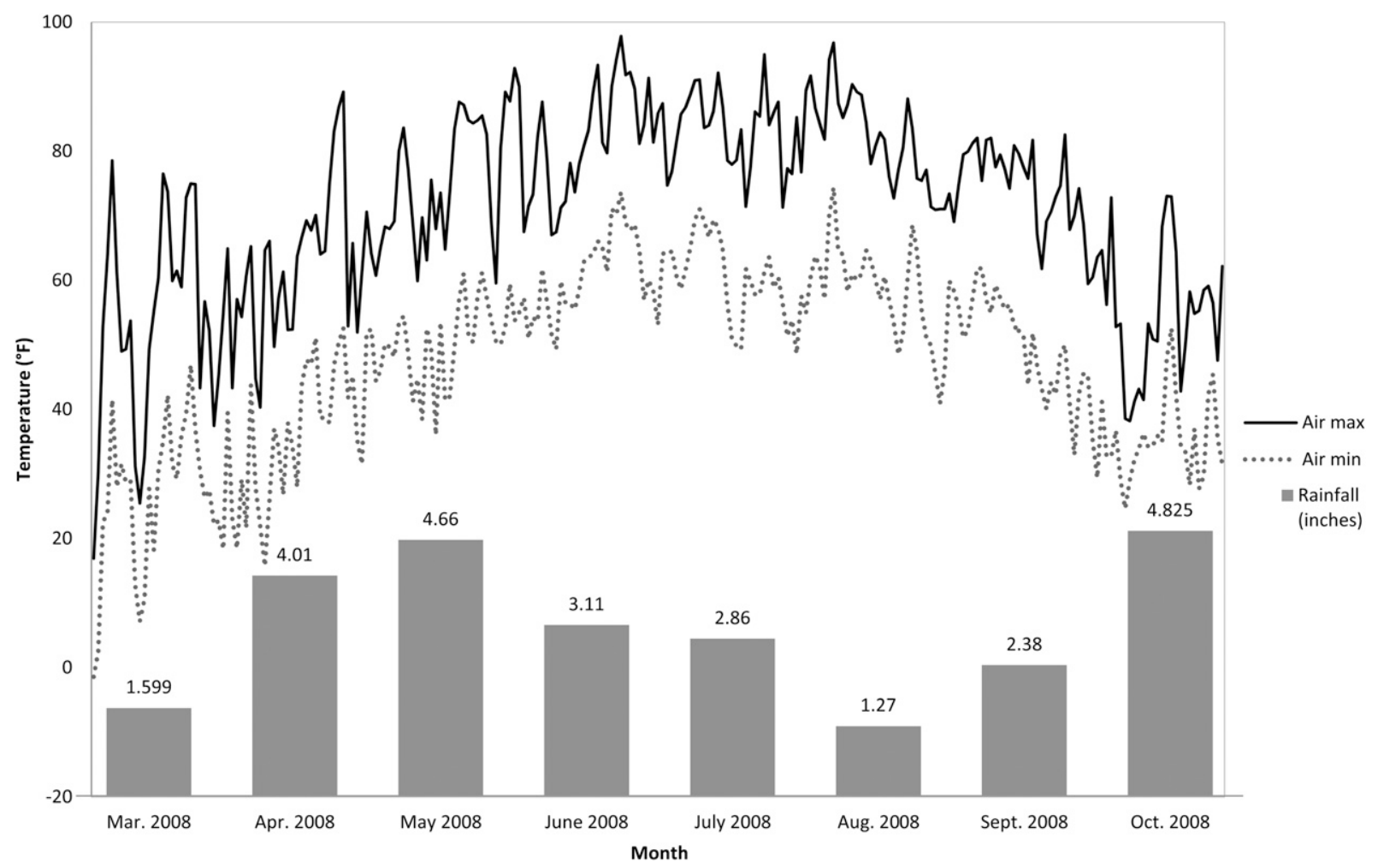

Fig. 1. Maximum and minimum daily air temperature and monthly rainfall precipitation near Crete, NE, during the 2008 growing season; $\left({ }^{\circ} \mathrm{F}-32\right) \div 1.8={ }^{\circ} \mathrm{C}, 1$ inch $=25.4 \mathrm{~mm}$. 
trellis and sample type (seed or skin) effects and a trellis by sample type interaction. Differences among the effects were examined with Tukey's adjustment. All significance tests used $\alpha=0.05$. Correlation analyses were performed using the GLIMMIX procedure.

\section{Results and discussion}

Trellis efFects ON Light ENVIRONMENT. At all sampling dates in 2008, vines grown on GDC and $\mathrm{HC}$ trellises had higher midday percentage $P A R$ transmittances than vines grown on SD and VSP training systems (Table 1). In 2009 the pattern was similar, except GDC had higher transmittance than $\mathrm{HC}$ at harvest and VSP had higher transmittance than SD at veraison (Table 1 ). There was a significant year by trellis by sampling date interaction, as evidenced by the differences in transmittance relationships between the years. In both years, LLN was lower for GDC and $\mathrm{HC}$ than for SD and VSP (Table 2). There was not a significant year by trellis interaction for LLN, so the differences presented are averaged over both years. GDC and $\mathrm{HC}$ had less dense canopies (higher transmittances and lower LLN) than the other trellises in this study. Open canopies optimize yield and fruit composition; they facilitate pruning, harvesting, and spray penetration. They also tend to have fewer disease problems because of their favorable canopy microclimates (Smart and Robinson, 1991). Light penetration (percentage $P A R$ transmittance) is generally negatively correlated with LLN (Vanden Huevel et al., 2004). In this study, training systems with low LLN values did have correspondingly high transmittances, though the correlation was not statistically significant.

Trellis efFects ON YIELD. This research demonstrated large differences in yield between training systems. GDC had the highest fruit yield of all trellises in 2008, and higher yield than HC and VSP in 2009 (Table 2), which is consistent with previous studies comparing the yield of other cultivars grown on GDC and other horizontally divided canopies to single-canopy controls (Reynolds et al., 1995; Shaulis et al., 1966; Smart et al., 1982). Generally, sunlight penetration and yield are positively correlated because increased shoot exposure improves bud fruitfulness (Perez and
Kliewer, 1990; Shaulis et al., 1966; Smart et al., 1982). Because HC had such high transmittance values, one would expect it to yield more than VSP, the only other single-canopy training system; however, HC suffered damage from birds because they were able to access its fruit through the netting. If the crop had been better protected, perhaps $\mathrm{HC}$ would have produced a higher yield than VSP. Based on the yields we recorded in 2009, at a vine spacing of 551 plants/acre (2.4 $\mathrm{m}$ between vines and $3 \mathrm{~m}$ between rows) and price of $\$ 1200 / t$ of fruit, the vineyard's gross income would have been $\$ 3062$ /acre for GDC, \$1833/acre for HC, \$2713 for SD, and \$2189/acre for VSP.

Trellis efFECTS ON FRUIT COMPosition. In 2008, GDC and $\mathrm{HC}$ had lower TA than other training systems (Table 3); this is in agreement with the findings of Smart et al. (1988) and Macaulay and Morris (1993) who observed higher TA in shaded treatments. In 2009, the trellises did not differ in TA despite observed differences in percentage $P A R$ transmittance (Table 3 ). In both years, all of the trellises exceeded the ideal TA concentration, which is

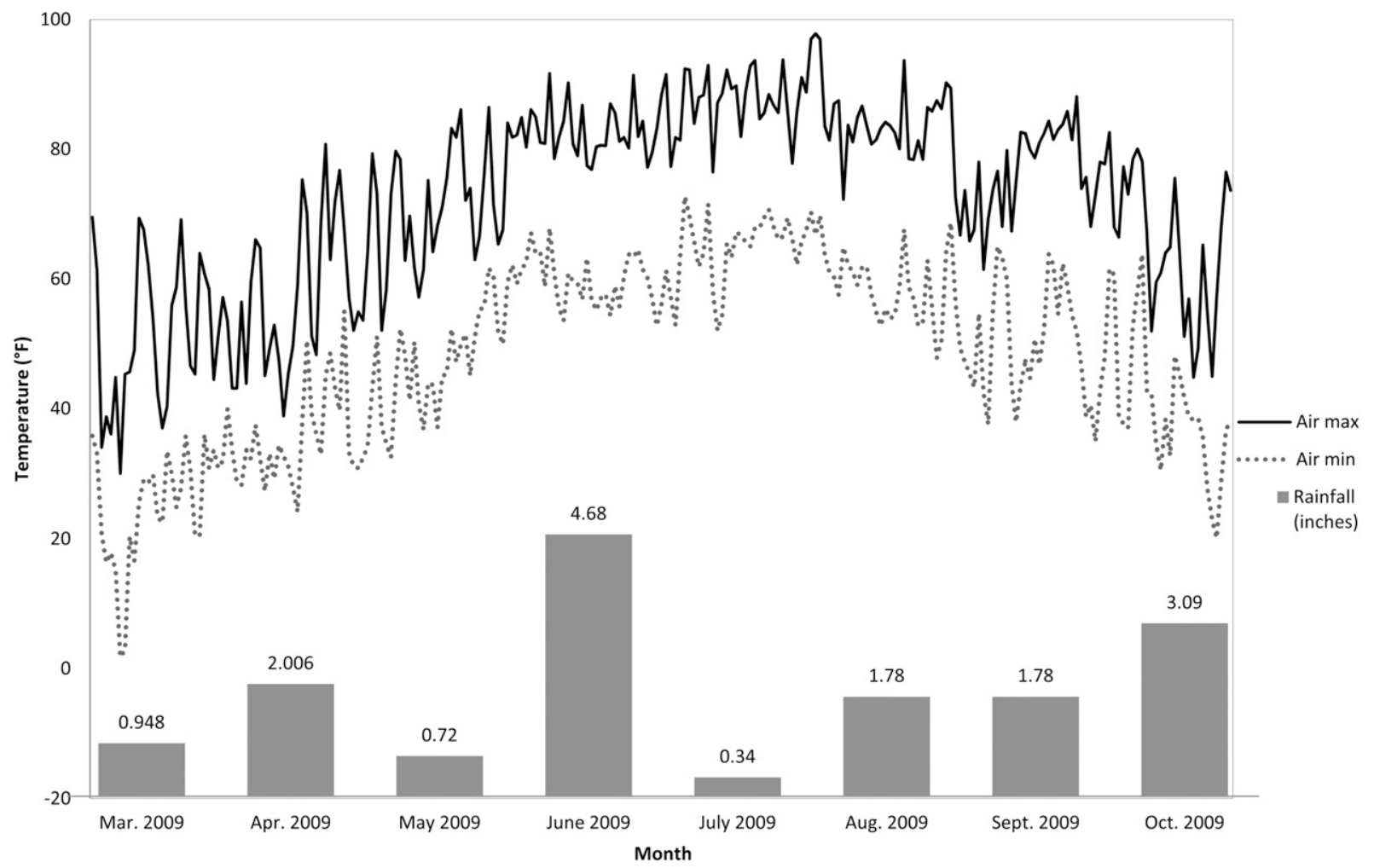

Fig. 2. Maximum and minimum daily air temperature and monthly rainfall precipitation near Crete, NE, during the 2009 growing season; $\left({ }^{\circ} \mathrm{F}-32\right) \div 1.8={ }^{\circ} \mathrm{C}, 1$ inch $=25.4 \mathrm{~mm}$. 
Table 4. Mean total phenol concentrations of skin and seeds of 'Frontenac' grapes grown on four training systems in southeastern Nebraska in 2008 . $^{\mathrm{z}}$

\begin{tabular}{|c|c|c|}
\hline Trellis $^{\mathrm{y}}$ & $\begin{array}{l}\text { Phenol concn of free } \\
\text { extract of skin and } \\
\text { seeds }\left(\mathrm{mg} \cdot \mathrm{g}^{-1} \text { dry } \mathrm{wt}\right)^{\mathrm{x}}\end{array}$ & $\begin{array}{l}\text { Phenol concn of combined } \\
\text { (free }+ \text { bound) extracts of skin } \\
\text { and seeds }\left(\mathrm{mg} \cdot \mathrm{g}^{-1} \text { dry wt) }\right.\end{array}$ \\
\hline GDC & $60.27 \mathrm{ab}^{\mathrm{w}}$ & $65.38 \mathrm{ab}$ \\
\hline $\mathrm{HC}$ & $61.70 \mathrm{ab}$ & $65.65 \mathrm{ab}$ \\
\hline SD & $51.60 \mathrm{~b}$ & $55.31 \mathrm{~b}$ \\
\hline VSP & $64.45 \mathrm{a}$ & $68.64 \mathrm{a}$ \\
\hline
\end{tabular}

${ }^{2}$ Statistical models included fixed effects of sample type (bound seed, bound skin, free seed, free skin), trellis, and their interactions. Statistical probability values for sample type, trellis, and their interaction for free extracts were $<$ $0.0001,0.0477$, and 0.2826 and for combined were $<0.0001,0.0382$, and 0.3320 , respectively. Because there were no significant interactions between trellis and sample type, we investigated the main effect of trellis averaged over sample type.

${ }^{y} \mathrm{GDC}=$ Geneva double curtain, $\mathrm{HC}=$ high cordon, $\mathrm{SD}=$ Smart-Dyson, VSP = vertical shoot positioning.

${ }^{\mathrm{x}} \mathrm{l} \mathrm{mg} \cdot \mathrm{g}^{-1}=1000 \mathrm{ppm}$.

"Means followed by the same letter within a column and sample type do not differ at $P \leq 0.05$ using Tukey's adjustment.

between $0.6 \%$ and $0.8 \%$ for red grape musts (Dharmadhikari and Wilker, 2001). This higher acidity is consistent with observations of 'Frontenac' fruit chemistry.

Fruit $\mathrm{pH}$ (Table 3 ) was not dependent on transmittance in this study, in agreement with Smart et al. (1988). In 2008, GDC had higher $\mathrm{pH}$ than other trellises although $\mathrm{HC}$ had comparable canopy conditions; in 2009, $\mathrm{HC}$ fruit had higher $\mathrm{pH}$ than SD and VSP, whereas GDC was intermediate. Soluble solids (Table 3 ) appeared related to fruit-zone transmittance in 2008, with GDC highest, followed by HC. Many others have observed the same pattern (Crippen and Morrison 1986; Smart et al., 1988, Spayd et al., 2002); however, in 2009, SD and VSP had the highest soluble solids. These results cannot be explained by canopy light environment. In 2008, there were no differences in berry weight, whereas in 2009 SD and VSP produced larger berries than HC (Table 3). Berries were larger in 2008 than in 2009 , likely due to differences in crop load and rainfall between the years (Figs. 1 and 2). Regression analysis (data not shown) showed only very weak correlations between fruit composition variables and percentage $P A R$ transmittance at veraison.

TRELLIS EFFECTS ON PHENOL AND FLAVONOID CONCENTRATIONS. There were no significant interactions among fixed effects of the statistical model, so we investigated the main effect of trellis averaged over sample type (skin and seeds). There was an overall significant difference among the training systems for total phenol concentration of unbound (free) extracts of seeds and skin, but not for bound extracts. Flavonoid concentrations did not differ significantly among trellises. Within the free extracts of seeds and skin, SD had lower total phenol concentration than VSP. The same pattern was also observed when free and bound extract concentrations were combined (Table 4).

Although many studies have shown reduced total phenolic content in shaded fruit (Cortell and Kennedy, 2006; Morrison and Noble, 1990; Smart et al., 1988; Wolf et al., 2003), in this study, flavonoids and total phenol concentrations of skins and seeds did not correspond to light availability in the canopy. VSP had higher free total phenol concentration and higher combined (free + bound) total phenol concentration than SD, although they did not differ in transmittance the year the fruit was collected. Bound total phenols, bound flavonoids, and free flavonoids did not differ among training systems, although significant differences in percentage $P A R$ transmittance were observed.

Human HEALTH implications. This research measured significant differences in the unbound phenolic content of grape seeds and skins, but no differences in the concentration of bound compounds or flavonoids. Distinguishing between free and bound phenolics is important because bound compounds can survive digestion by the stomach and small intestine, reaching the colon where intestinal microbes may release them for absorption and possibly local health benefits (Adom and Liu, 2002). This suggests that concentration of bound phenols may be a better indicator of potential health benefit than free or total phenolic content.
Additionally, some phenolic compounds have higher AOA than others (Di Majo et al., 2008; Yildirim et al., 2005). In a study of various red wines made from different grape cultivars, flavonoid concentrations were not significantly different although flavonoid composition varied greatly (Fang et al., 2008).

\section{Conclusions}

Although individual phenolic compounds were not identified in this study, it is possible that the composition and antioxidant capacity could have varied among trellis treatments, even though total flavonoid and phenolic concentrations were mostly not significantly different. Therefore, it would be problematic to draw conclusions on the health-promoting properties of the fruit in this study. Future research on grape and wine phenols and/or flavonoids should identify individual compounds where possible, since their AOA-and potential health benefits-are variable.

Of the four training systems evaluated in this research, we feel GDC is an appropriate choice for 'Frontenac' grown in the upper midwestern U.S. Although fruit quality results were inconclusive, GDC vines had the highest yield in both years of our study. Vines trained to GDC also had very favorable canopy conditions, as determined both by percentage PAR transmittance measurements and by point quadrat analysis.

\section{Literature cited}

Adom, K.K. and R.H. Liu. 2002. Antioxidant activity of grains. J. Agr. Food Chem. 50:6182-6187.

Cheynier, V., H. Fulcrand, F. Brossaud, C. Asselin, and M. Moutounet. 1999. Phenolic composition as related to red wine flavor, p. 124-141. In: A.L. Waterhouse and S.E. Ebeler (eds). Chemistry of wine flavor. American Chemical Society, Washington, DC.

Cheynier, V., M. Dueñas-Paton, E. Salas, C. Maury, J. Souquet, P. Sarni-Manchado, and H. Fulcrand. 2006. Structure and properties of wine pigments and tannins. Amer. J. Enol. Viticult. 57:298-305.

Cortell, J.M. and J.A. Kennedy. 2006. Effect of shading on accumulation of flavonoid compounds in (Vitis vinifera L.) Pinot noir fruit and extraction in a model system. J. Agr. Food Chem. 54: 8510-8520. 
Crippen, D.D. and J.C. Morrison. 1986. The effects of sun exposure on the compositional development of Cabernet Sauvignon berries. Amer. J. Enol. Viticult. 37:235-242.

Dami, I., B. Bordelon, D.C. Ferree, M. Brown, M. Ellis, R.N. Williams, and D. Doohan. 2005. Midwest grape production guide. Ohio State Univ. Ext. Bul. 919.

Dharmadhikari, M.R. and K.L. Wilker. 2001. Micro vinification: A practical guide to small-scale wine production. Missouri State Fruit Expt. Sta., Mountain Grove, MO.

Di Majo, D., M. La Guardia, S. Giammanco, L. La Neve, and M. Giammanco. 2008. The antioxidant capacity of red wine in relationship with its polyphenolic constituents. Food Chem. 111:45-49.

Dokoozlian, N.K. and W.M. Kliewer. 1995. The light environment within grapevine canopies. I. Description and seasonal changes during fruit development. Amer. J. Enol. Viticult. 46:209-218.

Downey, M.O., J.S. Harvey, and S.P. Robinson. 2004. The effect of bunch shading on berry development and flavonoid accumulation in Shiraz grapes. Austral. J. Grape Wine Res. 10:55-73.

Downey, M.O., N.K. Dokoozlian, and M.P. Krstic. 2006. Cultural practice and environmental impacts on the flavonoid composition of grapes and wine: A review of recent research. Amer. J. Enol. Viticult. 57:257-268

Fang, F., J. Li, P. Zhang, K. Tang, W. Wang, Q. Pan, and W. Huang. 2008. Effects of grape variety, harvest date, fermentation vessel and wine ageing on flavonoid concentration in red wines. Food Res. Intl. 41:53-60.

Gorinstein, S., R. Haruenkit, S. Poovarodom, S. Vearasilp, P. Ruamsuke, J. Namiesnik, M. Leontowicz, H. Leontowicz, M. Suhaj, and G.P. Sheng. 2010. Some analytical assays for the determination of bioactivity of exotic fruits. Phytochem. Anal. 21:355-362.

Holt, H.E., I.L. Francis, J. Field, M.J. Herderich, and P.G. Iland. 2008a. Relationships between berry size, berry phenolic composition and wine quality score for Cabernet Sauvignon (Vitis vinifera L.) from different pruning treatments and different vintages. Austral. J. Grape Wine Res. 14:191-202.

Holt, H.E., I.L. Francis, J. Field, M.J. Herderich, and P.G. Iland. 2008b. Relationships between wine phenolic composition and wine sensory properties for Cabernet Sauvignon (Vitis vinifera L.). Austral. J. Grape Wine Res. 14:162-176.
Howell, G.S., D.P. Miller, C.E. Edson, and R.K. Striegler. 1991. Influence of training system and pruning severity on yield, vine size, and fruit composition of Vignoles grapevines. Amer. J. Enol. Viticult. 42:191-198.

Iacopini, P., M. Baldi, P. Storchi, and L. Sebastiani. 2008. Catechin, epicatechin, quercetin, rutin and resveratrol in red grape: Content, in vitro antioxidant activity and interactions. J. Food Compost. Anal. 21:589-598.

Jia, Z., T. Mengcheng, and J. Wu. 1999. The determination of flavonoid contents in mulberry and their scavenging effects on superoxide radicals. Food Chem. 64:555-559.

Joscelyne, V.L., M.O. Downey, M. Mazza, and S.E.P. Bastian. 2007. Partial shading of Cabernet Sauvignon and Shiraz vines altered wine color and mouthfeel attributes, but increased exposure had little impact. J. Agr. Food Chem. 55:1088-10896.

Kennedy, J.A., C. Saucier, and Y. Glories. 2006. Grape and wine phenolics: History and perspective. Amer. J. Enol. Viticult. 57:239-248.

Koyama, K. and N. Goto-Yamamoto. 2008. Bunch shading during different developmental stages affects the phenolic biosynthesis in berry skins of 'Cabernet Sauvignon' grapes. J. Amer. Soc. Hort. Sci. 133:743-753.

Macaulay, L.E. and J.R. Morris. 1993. Influence of cluster exposure and winemaking processes on monoterpenes and wine olfactory evaluation of Golden Muscat. Amer. J. Enol. Viticult. 44:198-204.

Minnesota Agricultural Experiment Station. 2008. Cold Hardy Grapes: Frontenac Viticulture. 11 June 2012. <http://www. grapes.umn.edu/frontenac/index.html $>$.

Morrison, J.C. and A.C. Noble. 1990. The effects of leaf and cluster shading on the composition of Cabernet Sauvignon grapes and on fruit and wine sensory properties. Amer. J. Enol. Viticult. 41:193-200.

Perez, J. and W.M. Kliewer. 1990. Effect of shading on bud necrosis and bud fruitfulness of Thompson Seedless grapevines. Amer. J. Enol. Viticult. 41:168175.

Price, S.F., P.J. Breen, M. Valladao, and B.T. Watson. 1995. Cluster sun exposure and quercetin in Pinot noir grapes and wine. Amer. J. Enol. Viticult. 46:187-194.

Reynolds, A.G., D.A. Wardle, and A.P. Naylor. 1995. Impact of training system and vine spacing on vine performance and berry composition of Chancellor. Amer. J. Enol. Viticult. 46:88-97.

Ristic, R., M.O. Downey, P.G. Iland, K. Bindon, I.L. Francis, M. Herderich, and S.P. Robinson. 2007. Exclusion of sunlight from Shiraz grapes alters wine colour, tannin and sensory properties. Austral. J. Grape Wine Res. 13:53-65.

Santos-Buelga, C. and A. Scalbert. 2000. Proanthocyanidins and tannin-like compounds-nature, occurrence, dietary intake and effects on nutrition and health. J. Sci. Food Agr. 80:1094-1117.

Shaulis, N., H. Amberg, and D. Crowe. 1966. Response of Concord grapes to light, exposure and Geneva double curtain training. Proc. Amer. Soc. Hort. Sci. $89: 268-280$

Singleton, V.L. and J.A. Rossi, Jr. 1965. Colorimetry of total phenolics with phosphomolybdic-phosphotungstic acid reagents. Amer. J. Enol. Viticult. 16:144158.

Smart, R.E. and M. Robinson. 1991. Sunlight into wine: A handbook for winegrape canopy management. Winetitles, Adelaide, Australia.

Smart, R.E., N.J. Shaulis, and E.R. Lemon. 1982. The effect of Concord vineyard microclimate on yield. II. The interrelations between microclimate and yield expression. Amer. J. Enol. Viticult. 33:109-116.

Smart, R.E., S.M. Smith, and R.V.Winchester. 1988. Light quality and quantity effects on fruit ripening for Cabernet Sauvignon. Amer. J. Enol. Viticult. 39:250-258.

Spayd, S.E., J.M. Tarara, D.L. Mee, and J.C. Ferguson. 2002. Separation of sunlight and temperature effects on the composition of Vitis vinifera cv. Merlot berries. Amer. J. Enol. Viticult. 53:171-182.

Vanden Huevel, J.E., J.T.A. Proctor, J.A. Sullivan, and K.H. Fisher. 2004. Influence of training/trellising system and rootstock selection on productivity and fruit composition of Chardonnay and Cabernet franc grapevines in Ontario, Canada. Amer. J. Enol. Viticult. 55:253-264.

Wolf, T.K., P.R. Dry, P.G. Iland, D. Botting, J. Dick, U. Kennedy, and R. Ristic. 2003. Response of Shiraz grapevines to five different training systems in the Barossa Valley, Australia. Austral. J. Grape Wine Res. 9:82-95.

Yildirim, H.K., Y.D. Akçay, U. Güvenç, A. Altindişli, and E.Y. Sözmen. 2005. Antioxidant activities of organic grape, pomace, juice, must, wine and their correlation with phenolic content. Intl. J. Food Sci. Technol. 40:133-142. 